\title{
PATRIMONIAL RESOURCES' MANAGEMENT AND EFFECTS ON THE ECONOMIC VALUE ADDED
}

\author{
Vasile Burja ${ }^{1}$ \\ Camelia Burja ${ }^{2}$
}

\begin{abstract}
The core elements of one firm's existence as the patrimonial situation and performance, are related in a great measure by the business strategy adopted, the economic environment in which it is operating and the way of resources' management. An efficient management of all patrimonial resources can assure the obtaining of the superior financial results and of a higher value added. The principal goal of the paper is the presentation of the correlation between the patrimonial elements' rotation and the Economic Value Added indicator. The modality of evidencing the interdependence between EVA and the management of resources is the technique of modeling and financial analysis of the accounting data of the company. The theoretical findings are validated in a adequate case study and are useful for a better understanding of the creating value process and the increasing the economic performance.
\end{abstract}

Key words: resources management, economic value added, rotation speed, economic performance, analysis model

JEL classification: G12, G31, M21

\section{Introduction}

The value theory occupies a main place within economics due to the controverses related to the factors which generate the value and its economic, social and political implication. The attitude towards the mechanism of value creation, has generated genuine schools and economic thinking, and in this line D. Ricardo considers that the problem of value is the core element of any economic system (Hollander J. H., 1904).

The companies' management has as prior objective the substantiantig of the operating, investments and financial decisions, which ensure a higher added value, answering in this way to the shareholders' interests, that expect the adequate rewards for the invested capital and the risk assumed (Helfert, E.A., 2006). At the same time, the creation of value satisfies specific interests of the employees, creditors and national economy as a whole.

The evaluation of economic performance of companies in modern management is closely related with the added value created through their activity. This approach modifies the traditional perspective on performance which is based on net accounting profit obtained through subtracting from income of explicit costs, without taking into account expenses caused by use of own capital. Although the company registers profit, if it returns in the economy less than it received as resources, then the company does not create value, does not register economic performance and does not satisfy the interest of shareholders that expect payment on invested capital (Drucker, P., 1995).

The value created by companies can be measured through specific indicators like: Economic Value Added (EVA) Market Value Added (MVA) and Cash Value Added (CVA). The use of such indicators in economic analyses has confirmed their importance in correctly appreciating the

\footnotetext{
${ }^{1}$ University “1 Decembrie 1918” of Alba Iulia, 11-13 N. Iorga Street, Alba Iulia, Romania, vasileburja@yahoo.com

${ }^{2}$ University “1 Decembrie 1918” of Alba Iulia, 11-13 N. Iorga Street, Alba Iulia, Romania, cameliaburja@yahoo.com
} 
economic performance created by companies, their growth providing the expected satisfaction for the shareholders (Fernández P., 2002).

Economic Value Added is an indicator often used in the praxis of financial analyses, begining with 1991 when G.B. Stewart revises the computation of the residual income of some accounting adjusted data and thus establishes the methodology of computing EVA (Stewart, G., B., 1991). Considering the Economic Value Added (EVA) to be a means of expressing the economic results of a company, which takes into account the exploitation risk, a more thorough analysis of the EVA indicator from the perspective of an efficient management of economic resources immobilized assets, stocks, debts and monetary availabilities - becomes necessary. Used in production, they become economic goods and when sold, the conditions for restoring the financial sources necessary for the beginning of a new economic cycle are created.

During this development, there is also a permanent creation of EVA value, so that the pace with which the patrimonial elements of a company begin the economic cycle directly influences the level of the Economic Value Added.

The indicator that measures synthetically the efficiency of resource management is the rotation speed based on the rate of turnover, expressed either by the number of rotations that a resource undergoes during a certain period of time, either by the number of days of a rotation in which the economic cycle is completely achieved. These indicators actually determine a complete renewal of patrimonial elements through the turnover rate.

In the paper it is proposed an analysis model that allows the identification of the main influences on the economic value added by a firm. The operationalisation of the analysis model on the case of the industrial company shows the correlation between the rotation of assets and the added economic value, being useful for substantiating the decisions required in order to increase the economic performance.

\section{The analysis model for correlation between resources rotation and value creation}

In order to develop an adequate model for analyzing the implications of the actions of the resources rotation speed on the value creation, we will start from the relation of determining the Economic Value Added according to the economic notion that it represents a residual income (excess profit) (Magni C. A., 2001):

$$
\begin{gathered}
E V A=(R O I-W A C C) \cdot K I \\
E V A=N O P A T-C K I \quad \text { or } \quad E V A=N O P A T-K I \cdot W A C C
\end{gathered}
$$

The significance of the symbols is the following:

$R O I$ represents return on invested capital;

NOPAT - net operating profit after tax;

CKI - $\quad$ cost of invested capitals;

$K I \quad$ - invested capitals;

WACC - weighted average cost of capital.

By introducing into the calculus equation of the Economic Value Added the specific elements of analyzing resource management, and namely the rate of turnover $(C A)$ resulted from exploitation and merchandising as well as the period for which the analysis is conducted $(T)$, it is possible to study EVA through the qualitative management analysis of resources that were used to obtain it.

Formula (2) becomes: 


$$
\begin{gathered}
E V A=\left(\frac{N O P A T}{C A} \cdot T-\frac{K I \cdot W A C C}{C A} \cdot T\right) \cdot \frac{C A}{T} \\
E V A=(D z N O P A T-D z C K I) \cdot c a
\end{gathered}
$$

or

$$
E V A=(D z N O P A T-D z K I \cdot W A C C) \cdot c a
$$

where:

DzNOPAT represents the rotation speed of NOPAT through the turnover;

$D z C K I$ - the duration in days when the invested capital is recovered through the turnover;

$D z K I \quad$ - the duration in days of the rotation of invested capitals;

ca - daily average sales;

Expressing the invested capital depending on its economic destination and namely to finance the permanent needs of the company, to finance exploitation and monetary availabilities and placements, relationship (3) becomes:

$$
E V A=\left(D z N O P A T-\frac{(A I+N F R+D b) \cdot W A C C}{C A} \cdot T\right) \cdot c a
$$

where the invested capital was replaced by the relationship:

$$
K I=A I+N F R+D b
$$

The notations have the following significance:

$A I$ represents immobilized assets (permanent financing need);

NFR - necessary working capital (temporary financing need);

$\mathrm{Db} \quad$ - monetary availabilities and placements.

The relationship to determine the Economic Value Added changes into:

$$
\begin{gathered}
E V A=[D z N O P A T-(D z A I+D z N F R+D z D b) \cdot W A C C] \cdot c a \\
\text { and } W A C C=\frac{\sum g_{i} \cdot k_{i}}{100}
\end{gathered}
$$

The unknown symbols are:

$D z A I$ represents the rotation speed of immobilized assets, in days;

$D z N F R \quad$ - the rotation speed of the working capital necessary, with the significance of number of days in which the financing sources of temporary exploitation needs are ensured;

$D z D b$ - duration in days of the rotation of monetary availabilities and placement through the rate of turnover;

$g_{i} \quad-\quad$ structure of different types of engaged capitals (\%);

$k_{i} \quad-\quad$ relative cost size for various types of invested capitals (\%). 
It has been observed that the Economic Value Added directly depends on the time period in which the company's exploitation activity can generate profit, on the amount of daily average sales and vice versa, on the time period in which the company can recover the cost of invested capitals based on the rate of turnover. Through the time period for recovering the cost of capitals engaged in business, the measure of EVA depends on the rotation speed of invested capitals and on the measure of the weighted average cost of the respective capitals. Through these factors, there are other elements as well which influence EVA: the rotation speed of immobilized assets, the rotation speed of the working capital necessary, the rotation speed of monetary availabilities and placements, the capital structure, the amount of various sources for business financing.

Further on, we shall present the proposed model of factor analysis for the Economic Value Added, which highlights the economic significant factors from the viewpoint of the resource management method that should be used in substantiating the decisions within the companies. Although the economic factors that interact with EVA are easily identified, their relative impact on the final outcome is often hard to determine (Prakash D., Tarun K. M., 2007).

We can identify the modification of the Economic Value Added due to the action of the whole complex of factors through the following relation:

$$
\triangle E V A=\left(D z N O P A T_{1}-D z C K I_{1}\right) \cdot c a_{1}-\left(D z N O P A T_{0}-D z C K I_{0}\right) \cdot c a_{0}
$$

The quantifying of the factors' influence is as follows (from relation 4):

1. The influence of the rotation speed of NOPAT:

$$
\triangle E V A(D z N O P A T)=\triangle D z N O P A T \cdot c a_{0}
$$

2. The influence of the period of recovering the cost of capital invested in the business:

$$
\triangle E V A(D z C K I)=-\Delta D z C K I \cdot c a_{0}
$$

of which (from relation 5):

2.1. The influence of the rotation speed of the invested capital:

$$
\Delta E V A(D z K I)=-\Delta D z K I \cdot W A C C_{0} \cdot c a_{0}
$$

of which (from relation7):

2.1.1. The influence of the rotation speed of immobilized assets:

$$
\Delta E V A(D z A I)=-\Delta D z A I \cdot W A C C_{0} \cdot c a_{0}
$$

2.1.2. The influence of modifying the duration of NFR coverage on the turnover:

$$
\Delta E V A(D z N F R)=-\Delta D z N F R \cdot W A C C_{0} \cdot c a_{0}
$$

2.1.3. The influence of the modification of the rotation speed (management) of monetary availabilities and placements:

$$
\triangle E V A(D z D b)=-\Delta D z D b \cdot W A C C_{0} \cdot c a_{0}
$$

2.2. The influence of the modification of the weighted average cost of capital: 


$$
\triangle E V A(W A C C)=-D z K I_{1} \cdot \Delta W A C C \cdot c a_{0}
$$

of which (from relation 8):

2.2.1. The influence of the invested capital's structure:

$$
\Delta E V A\left(g_{i}\right)=-D z K I_{1} \cdot \frac{\sum g_{1} k_{0}-\sum g_{0} k_{0}}{100} \cdot c a_{0}
$$

2.2.2. The influence of the modification of the relative cost of financing sources:

$$
\Delta E V A\left(k_{i}\right)=-D z K I_{1} \cdot \frac{\sum g_{1} k_{1}-\sum g_{1} k_{0}}{100} \cdot c a_{0}
$$

3. The influence of daily average sales:

$$
\Delta E V A(c a)=\left(D z N O P A T_{1}-D z C K I_{1}\right) \cdot \Delta c a
$$

Through application into practice of this factor analysis model can be quantified the specific influences of the main factors related to the economic and financial activity of an enterprise. Their better management generates a greater Economic Value Added and that it will be a basis for improving of the company's performance indicators.

\section{Applying the analysis model}

From the financial statements of the industrial company it was selected data concerning the patrimonial resources used in activity. The following case study is used to exemplify the model of factorial analysis for the Economic Value Added.

The indicators necessary for EVA analysis are presented in table 1.

The calculus of Economic Value Added

\begin{tabular}{|l|c|c|}
\hline \multicolumn{1}{|c|}{ Indicators } & $\begin{array}{c}\text { Year } \\
\text { n-1 }\end{array}$ & $\begin{array}{c}\text { Year } \\
\text { n }\end{array}$ \\
\hline Turnover (thou RON) & 27461 & 31198 \\
\hline Invested capital (thou RON): & 23191 & 24498 \\
\hline - Immobilized assets & 12615 & 14660 \\
\hline - Working capital necessary & 9671 & 8663 \\
\hline - Monetary availabilities and placements & 905 & 1175 \\
\hline Weighted average cost of capital (\%) & 14.47 & 15.32 \\
\hline Cost of capital invested (thou RON) & 3356 & 3753 \\
\hline Daily average of turnover (thou RON) & 75.23 & 85.47 \\
\hline Rotation speed of NOPAT (days) & 48.01 & 47.32 \\
\hline $\begin{array}{l}\text { Rotation speed of the cost of invested capitals } \\
\text { (days) }\end{array}$ & 44.61 & 43.91 \\
\hline Rotation speed of invested capitals (days) & 308.24 & 286.61 \\
\hline Rotation speed of immobilized assets (days) & 167.67 & 171.51 \\
\hline $\begin{array}{l}\text { Rotation speed of working capital necessary } \\
\text { (days) }\end{array}$ & 128.54 & 101.35 \\
\hline
\end{tabular}




\begin{tabular}{|l|c|c|}
\hline $\begin{array}{l}\text { Rotation speed of availabilities and placements } \\
\text { (days) }\end{array}$ & 12.03 & 13.75 \\
\hline Net operating profit after tax (thou RON) & 3612 & 4045 \\
\hline Economic Value Added (thou RON) & 256 & 292 \\
\hline Relative cost of own capital (\%) & 14.6 & 15.4 \\
\hline Relative cost of loans (\%) & 14 & 15 \\
\hline Weight of own capital (\%) & 78 & 80 \\
\hline Weight of loan capital (\%) & 22 & 20 \\
\hline
\end{tabular}

Source: company's financial statements and calculated dates

The presented model has been put into operation on the base of the situation illustrated in table 1. A synthesis of the results obtained in the EVA analysis is presented in table 2:

Table no. 2

The sysnthesis of factor influence on EVA

\begin{tabular}{|l|c|c|}
\hline \multicolumn{1}{|c|}{ The influence of factors on $\boldsymbol{E V A}$} & Symbol & $\begin{array}{c}\text { Thousand } \\
\text { RON }\end{array}$ \\
\hline 1. Rotation speed of NOPAT & $\triangle E V A(D z N O P A T)$ & -51.91 \\
\hline 2. Rotation speed of the cost of invested capitals & $\Delta E V A(D z C K I)$ & 52.66 \\
\hline 2.1. The rotation speed of the invested capital & $\Delta E V A(D z K I)$ & 235.45 \\
\hline 2.1.1. The rotation speed of immobilized assets & $\Delta E V A(D z A I)$ & -41.80 \\
\hline $\begin{array}{l}\text { 2.1.2. The rotation speed of working capital } \\
\text { necessary }\end{array}$ & $\Delta E V A(D z N F R)$ & 295.98 \\
\hline $\begin{array}{l}\text { 2.1.3. The rotation speed of availabilities and } \\
\text { placements }\end{array}$ & $\Delta E V A(D z D b)$ & -18.72 \\
\hline 2.2. The weighted average cost of invested capital & $\Delta E V A(W A C C)$ & -183.27 \\
\hline 2.2.1. The structure of the invested capital & $\left.\Delta E V A\left(g_{i}\right)\right)$ & -2.16 \\
\hline 2.2.2. The relative cost of financing sources & $\Delta E V A\left(k_{i}\right)$ & -181.11 \\
\hline 3. Daily average sales & $\Delta E V A(c a)$ & 34.92 \\
\hline Modification of $E V A$ & $\Delta E V A$ & 35.67 \\
\hline Modification of $N O P A T$ & $\Delta N O P A T$ & 433 \\
\hline
\end{tabular}

The factorial analysis of the Economic Value Added allows us to identify the causes that in a direct and an indirect way have led to the evolution of this indicator, which presents a special significance for the investors.

Although the net profit dynamics was positive, registering an increasing of 433 thousand RON, when following the evolution of the Economic Value Added by the company in the analyzed period, we can observe that it registers a lower dynamic than of NOPAT's, its increasing being only of 35.67 thousand RON. Resource management was only efficient in the production activity ( $E V A$ increased due to the working capital necessary by 295.98 thousand RON). The wrong management of immobilized assets produced losses of 41.8 thousand RON. Likewise, the management of monetary capital led to a decrease of EVA by 18.72 thousand RON.

On the whole, the company's economic activity was characterized by a proper management of its invested capital (235.45 thousand RON), which led to a better capitalization of invested capitals, to an extension of the time period in which the company obtained profit from the exploitation of available resources (21.63 days). The action of the net operating profit was negative; its influence was materialized in a decrease of EVA with 51.91 thousand RON. The merchandising 
policy that the company adopted had a positive influence, leading to an increase of the Economic Value Added by 34.92 thousand RON.

It registered an increase of the Economic Value Added due to the influence of the rotation speed of the cost of invested capital with 52.66 thousand RON, despite that this element manifested a slowing to be covered through the company's turnover.

Yet, solutions are needed to reduce the period of recovering the cost of invested capital that leads in great measure to weak results. The lever of $15.32 \%$ of the cost of invested capital (higher with 0.85 than previous year) represents a supplementary financial expense for the company and that is why the influence of that factor, determines a diminishing of EVA indicator with 181.11 thousand RON. For the analyzed company, the cost of capital proves to be too high and cannot be covered from the results obtained through economic resources management. Keeping the capitals engaged in this business in the future would imply a significant risk.

In order to obtain a positive created value, the company needs to act more intensely to do a better resources management (immobilized assets, circulating assets) so that it decreases the number of days in which the assets are recovered based on the turnover, increase the total profit obtained during the analyzed period, reduce the cost of financial sources used in its activity, together with a more active sales policy.

\section{Conclusions}

Understanding the mechanism of creating value is a prioritary objective for financial analyses because EVA is percived as an abstract notion, thus its degree of aprehension, accesibility and utility is reduced, or otherwise is perceived superficially, being reduced to the generated income. The management of performance based on created value has a fundamental role in corporate governance and, through its transposal in the praxis of enterprises, the intrested factors (shareholders, management, employees, clients, suppliers, financial and fiscal institutions) are motivated and educated to differentiate activities through which value is created from activities that destroy value (Aggarwal R., 2001), (Caby, J., Hirigoyen, G., 2005).

The economic activity is characterised by the existence of non-material and financial flows, that ensure in a permanent circuit the continous renewal of patrimonial elements through the total income. The rotation speed of the patrimony, directly influences the added economic value obtained through the economic activity of companies, through the way in which each patrimonial element is managed.

Financial analyses offers the specific tools for cuantifying the influence of the rotation speed of the patrimonial elements on the added economic value and implicitely on the economic performance. The task of the management is to valorify the internal reserves of companies so that it leads to increase in rotation speed and improves the value of added economic value, thus serving the interests of shareholders and other interested factors.

\section{References}

1. Aggarwal R., 2001. Using Economic Profit to Assess Performance: A Metric for Modern Firms, Business Horizons, vol. 44, issue 1, pp. 55-60

2. Caby, J., Hirigoyen, G., 2005. Création de Valeuret Gouvernance de l'Entreprise, Economica, Paris

3. Drucker, P., 1995. „EVA measurements”, Harvard Business Review

4. Fernández P., 2002. Valuation Methods and Shareholder Value Creation, Academic Press, pp.266-288

5. Helfert, E.A., 2006. Techniques of Financial analysis a guide to value creation, BMT Publishing House, Bucharest

6. Hollander J. H., 1904. „The development of Ricardo's theory of value”, Quarterly Journal of Economics, volume 18, pp. 455-491 
7. Magni C. A., 2001. Systemic Value Added: an alternative to EVA as a residual income model, Budget vol. 25, issue 1, Published by Elsevier Science, pp. 63-71

8. Prakash D., Tarun K. M., 2007. A practical approach to EVA analyses and issues, Review of Business Research

9. Stewart, G., B., 1991. The Quest for Value, New York: Harperbusiness 